\title{
The Impact of Perceived Value on Satisfaction of Adventure Tourists: With Special Reference to Sri Lankan Domestic Tourists
}

\author{
W. N. Hettiarachchi ${ }^{\mathrm{a} \varpi}$, H. M. A. Lakmal ${ }^{\mathrm{a}}$ \\ ${ }^{a}$ Department of Marketing Management, University of Sri Jayewardenepura, Sri Lanka
}

\begin{abstract}
This paper aims to investigate the drivers of customer value and their respective influence on satisfaction in the particularly under-researched area of adventure tourism with reference to the Sri Lankan domestic context. The multidimensional perceived value framework (PERVAL) was used and the study adopted a quantitative, explanatory and single cross-sectional research design. Convenient sampling method was used and 267 responses were evaluated through a structured questionnaire which was employed targeting domestic tourists who have participated in any kind of adventure activity in Sri Lanka. Results of regression analyses concluded that there is a direct and positive influence of perceived value on satisfaction in an adventure tourism setting. Furthermore, Sri Lankan domestic tourists attached more importance to novelty value and emotional value. The foremost implication of this study is that adventure tour operators should account for differences in value perception especially novelty highs like thrill, fear, curiosity and authenticity for domestic tourists when planning tour operations and itineraries.
\end{abstract}

Keywords: Tourists' Satisfaction, Perceived Value, PERVAL Value Scale, Adventure Tourism

Received:

17 January 2018
Accepted revised version:

04 April 2018
Published:

30 June 2018

Suggested citation: Hettiarachchi, W.N., \& Lakmal, H.M.A. (2018). The impact of perceived value on satisfaction of adventure tourists: With special reference to Sri Lankan domestic tourists. Colombo Business Journal. (9)1, 80-107

DOI: http://doi.org/10.4038/cbj.v9i1.23

(C) 2018 The Authors. This work is licenced under a Creative Commons Attribution 4.0 International Licence which permits unrestricted use, distribution, and reproduction in any medium, provided the original work is properly cited.

$\bowtie$ warunikanh@gmail.com; (iD) https://orcid.org/0000-0003-3513-2786 


\section{Introduction}

The travel and tourism industry is one of the fastest growing and the largest sectors of the world economy (World Travel \& Tourism Council, 2018). In many countries of the world, tourism activities are considered as more important than production and other services, concerning its economic and social aspects (Agaraj \& Murati, 2009). In the post era of 26 years of war, now Sri Lanka is benefiting the development of its tourism industry (Lokuhetty, Jayawardena \& Mudadeniya, 2013; Sri Lanka Tourism Development Authority, 2016). The total contribution of the tourism sector to Sri Lanka's GDP was 11.6\% in 2017 (World Travel \& Tourism Council, 2018) and employment generation in the tourism sector (both direct and indirect) was $11 \%$ of the total employment which was 875,000 in 2017 (World Travel \& Tourism Council, 2018).

Majority of tourists (53\%) visit a destination for leisure, recreation and holiday purpose (World Tourism Organization, 2017) and adventure tourism has become an important component of that segment. The commercialisation of adventure-based experiences and ecotourism are the fastest growers within the world tourism industry with an approximate growth of 15\%-20\% per year which represents more than $25 \%$ of the tourism market (Agaraj \& Murati, 2009; Williams, Souther, Ashill \& Naumann, 2017). Different adventure tourism destinations and products have emerged to convene the growth in demand ranging from 'soft' adventure activities (less demanding physical effort) to 'hard' adventure experiences (generally comprise physical or mental challenge) (Williams et al., 2017). Besides, adventure tour experiences can be further classified as land-based, water-based and air-based activities and domestic tourists can experience all these three kinds of activities in Sri Lanka (see Appendix).

New trends such as baby boomers being more interested to have adventurous experiences, women being as likely as men to take adventure trips, increasing trend in family adventure travels and more concern on eco-tourism have caused the rising demand in adventure tourism (World Tourism Organization, 2014). However, despite the growing popularity of adventure tourism worldwide and even locally, little research attention has been paid to this arena (Naidoo, Ramseook-Munhurrun, Seebaluck \& Janvier, 2015; Sung, 2004) and it has created new and exciting research opportunity (Buckley, 2007; Keeling, 2003) which was partially addressed through this study. 
According to Kozak and Rimmington (2000) tourists' satisfaction is vital in successful destination marketing since it influences the selection of a destination, consumption of products/services and decision to return. Hence, in order to uplift repeat visitation and recommendation intention, tourists' satisfaction is a prerequisite. However, the satisfaction of adventure tourists' is under-researched. From the perspective of service marketing, customer value is an imperative element in consumers' consumption and decision making behaviour (Sweeney, Soutar, \& Johnson, 1999). Although several studies (e.g. Bajs, 2015; Gill, Byslma, \& Ouschan, 2007; Oh, 1999) have examined the influence of the tourist perceived value on various aspects, lack of studies focused on the impact of different value dimensions of the PERVAL value scale. This study used a multidimensional value model as its core framework which was initially suggested by Sheth, Newman, and Gross (1991) and developed by Sweeney and Soutar (2001) into multi-dimensional PERVAL value scale. As per this scale, customer selection is a function of multiple consumption value dimensions (social, emotional, functional, novelty and value for money). Consequently, in order to fill the above-mentioned gaps and to endow important insights, this formal investigation on domestic adventure tourism in Sri Lanka was undertaken by addressing the research question of 'does perceived value impact on the satisfaction of domestic adventure tourists in Sri Lanka?'

The whole of Sri Lanka was considered for the study context without specifying a particular destination or a selected adventure activity. However, the scope of this study has been limited to the domestic tourism sector. Though the flow of overseas tourists to Sri Lanka is seasonal (Bandara, 2003), domestic tourism has fewer seasonal fluctuations. Thus, the development of domestic tourism will be resulted in proper utilisation of resources by minimising unused capacities. Nowadays, more Sri Lankans are seeking leisure time activities with productive and satisfactory level experiences (Sri Lanka Tourism Development Authority, 2016). As per the World Travel and Tourism Council (2018), the Sri Lankan domestic travel spending has generated 34.5\% of direct travel and tourism GDP in 2017 and this is expected to grow. According to the findings of Chen, Prebensen, and Muzaffer (2016) and Williams et al. (2017), perceived value of tourists, their satisfaction and interactions are significantly different from nation to nation. Hence, the findings of this study are expected to be supportive to reveal the behavioural patterns of the Sri Lankan domestic adventure tourists, and it will be useful to the development of the tourism sector of the country. Thus, two main research objectives have been formed as to identify the impact of overall perceived value on satisfaction and to examine the impact of dimensions of perceived value on satisfaction. 


\section{Literature Review}

According to World Tourism Organization (2014) tourism is the act of travelling and staying outside the usual environmental setting, for not more than one consecutive year of time period for leisure, business or any other purpose. Domestic traveller is an individual residing in the country who travels to a place inside the country, outside his/her usual environment for not more than consecutive twelve months of time period and the foremost reason for the visit is not an activity remunerated from within the place visited. By following the definitions of Weiler and Hall (1992), and Sung, Morrison, and O'Leary (1996), Fluker (2005) has defined adventure tourism as follows:

Adventure tourism represents a broad spectrum of risk-oriented outdoor tourist activities that are delivered on a commercial basis where profit is the key motive for the providers and are characterised by the deliberate seeking and/or acceptance of risk by the tourist and in which the outcome is influenced by the participant, the setting and the careful management of the experience. (p. 5)

Millington, Locke, and Locke (2001) have defined an adventure travel as a leisure activity which tends to relate to an excessive level of physical activity which takes place in an unusual, exotic and remote or wilderness destination.

Adventure level can be primarily based on the individual perception of risk and this may be inherent in the traveler, his/her background setting and prior life experiences (Weber, 2001). Adventure is an engagement rather than passive experience and this engagement can be either physical, emotional, intellectual or even spiritual level combing with the effort, commitment and often mental and physical preparation or training (Beard, Swarbrooke, Leckie \& Pomfret, 2011). According to Ewert and Hollenhorst (1989), risk and uncertainty of the outcome are associated with adventure activities. Furthermore, the decision to participate may decline, if the risk is absent. Consequently, in this setting, risk is usually treated as the physical risk of serious injury or death (Buckley, 2010). The term adventure really means differently to different tourists since things that form fear of one tourist might not fill up for another (Buckley, 2010). Thus, adventure, which is highly personal, is not an absolute concept and depends on experience and personality of people (Beard et al., 2011).

Adventure activities can be in the form of hard adventure or soft adventure (Patterson \& Pan, 2007; World Tourism Organization, 2014). Soft adventure 
activities consist of low degrees of actual risk, low physical effort and most of these activities can be led by experienced guides where hard adventure activities comprise excessive degrees of risk, requiring extreme commitment and advanced skills (Schott, 2007; Williams et al., 2017). If any tourist seeks challenging, novel and exciting consumption experiences while in holiday, then he/she is called an "adventure tourist" (Williams \& Soutar, 2009). Tran and Ralston (2006) found that most of the adventure tourists are people who are motivated by their achievements.

\section{Customer Satisfaction}

Satisfaction is one of the trendy and popular research areas within the tourism field (Correia, Kozak, \& Ferradeira, 2013). As defined by Oliver (2014, p.8), "satisfaction is the consumer's fulfilment response. It is a judgment that a product/service feature, or the product or service itself, provided (or is providing) a pleasurable level of consumption-related fulfilment, including levels of under or over fulfilment". Bruhn and Egan (2003) have defined customer satisfaction as customers' experience based evaluation of how far their personal expectations regarding the overall functionality of the service offering received were fulfilled. Further, Kotler and Keller (2006) have defined satisfaction as an individual's feeling of pleasure or disappointment occurred due to the comparison between a product's performance (outcome) and his/her expectation.

Ensuring the satisfaction of tourists is the key for the development of all kinds of tourism businesses since it can establish the success or the failure of that business. Thus, satisfaction plays a vital role in the planning process of marketable tourism products and services (Khuong \& Luan, 2015). It is important for both consumers and service providers. As per $\mathrm{Yu}$ (2012) in consumer perspective, satisfaction is a self-evident pursuit to be obtained by using a service and in providers' point of view, satisfaction gives both short term and long term impacts.

Too high expectations do not always lead to high satisfaction since, the actual experience of customers should be close to what they expected (C. F. Lee, 2015). Therefore, the efforts should always be directed towards either not to raise expectations too high nor keep expectations too low since it may possibly not convert a potential demand into a positive one (Lather, Singh \& Singh, 2012).

In attempting to improve customer satisfaction, it is important for marketers to identify antecedents of this construct and customer value has been identified as a 
key antecedent of satisfaction (Gallarza, Saura, \& Holbrook, 2011; Williams et al., 2017).

\section{Customer Perceived Value}

The perspective of 'perceived value' has emerged as the defining business matter in 1990s and it is continuing of receiving extensive research interest even in the present era (Mayr \& Zins, 2012; Sanchez-Fernandez \& Iniesta-Bonillo, 2007). According to Sanchez-Fernandez and Iniesta-Bonillo (2007), customer loyalty and profits are highly connected with the value which is created for customers.

Zeithaml (1988), Zeithaml and Bitner (2003) have described 'value' as consumer's overall evaluation of the utility of a product according to the perception of what they have received and what has been given to acquire it. This opinion hypothesises 'perceived value' as a uni-dimensional construct. Later, some researchers argued that 'perceived value' is a multidimensional construct rather a uni-dimensional one, where a variety of notions (e.g. perceived price, benefits, quality and sacrifice) are all included (Roig, Garcia, Tena \& Monzonis, 2006; Sweeney \& Soutar, 2001). In the uni-dimensional approach, perceived value has been considered as an independent concept and measured as a single variable, where in the multidimensional approach, value has been identified as a construct comprising several variables (Sanchez-Fernandez \& Iniesta-Bonilla, 2007).

Furthermore, the widely accepted definition for perceived value is customers' evaluation of the trade-off between benefits and sacrifices in selecting a particular product or service among the alternatives available in market (Chen \& Dubinsky, 2003; McDougall \& Levesque, 2000; Sanchez-Fernandez \& Iniesta-Bonilla, 2007). Perceived benefits are the feeling of what they have received by acquiring a product/service such as perceived quality, features of the product (internal and external) and other psychological benefits (Zeithaml, 1988). Perceived sacrifices can be identified as primary associations with the price as monetary cost and nonmonetary costs such as physical and mental effort, cost of time and lifestyle changes related with consuming the product or service (Snoj, Pisnik, \& Mumel, 2004).

\section{Perceived Value in the Tourism Industry}

According to Murphy, Pritchard and Smith (2000), in the context of tourism, the perceived value symbolises a trade-off among the travel time, money spent by 
travellers and the experience gained through the visit of the destination. Tourists can evaluate the value of a tour based on the difference between perceived benefits against perceived costs of the destination offerings (Bajs, 2015). Tourists usually perceive in favour of value when the benefits received by traveling are greater than the invested costs for the tour (Williams \& Soutar, 2009).

In service contexts such as tourism, a multi-dimensional perspective of value is often considered as more appropriate (Petrick, 2001; Sweeney \& Soutar, 2001; Williams \& Soutar, 2009; Williams et al., 2017) as the psychological and sociological aspects of consumption are more important for building up a better interaction between the service provider and the consumer, along with the heterogeneous nature of the service experience (Holbrook, 1994). The multidimensional value framework used in this study is the PERVAL value scale. This model was initially suggested by Sheth et al. (1991) and developed by Sweeney and Soutar (2001) into multi-dimensional PERVAL scale. As per the broader theoretical framework developed by Sheth et al. (1991), customer choice is a function of multiple dimensions of value where those dimensions create a diverse contribution in different situations. Sheth et al. (1991) have suggested five value dimensions, namely, functional, emotional, social, epistemic and conditional value, relating to perceived utility of the choice. This has been initially applied to different consumer products, later on to different services including the tourism sector (Williams \& Soutar, 2009). It has been suggested that out of the different dimensions of value, emotional benefits might be extremely important in the evaluation process of perceived value of a tour or a destination, (Sanchez, Callarisa, Rodriguez \& Moliner, 2006), since it has an impact on both satisfaction and intention to revisit with the effect of factors such as relaxation, enjoyment, and novel experience. (Bajs, 2015).

\section{Conceptualization}

Two hypotheses were developed, addressing the two objectives of this study. Under the second objective, several sub-hypotheses were developed in relation to the impact of each value dimension.

\section{Overall Perceived Value and Satisfaction}

Heung, Qu, and Chu (2001) argued that travellers take decisions regarding their satisfaction based on how they perceived the experience and thus it is vital that tourists distinguish the service as a value creation in order to satisfy them. Many researchers have confirmed that value perception is positively linked to post- 
consumption constructs of satisfaction and repurchase intentions (Cronin, Brady, \& Hult, 2000; McDougall \& Levesque, 2000). Bajs (2015) and Williams and Soutar (2009) have identified a strong positive correlation between perceived value and satisfaction in the tourism context. Furthermore, findings of the studies done by Bradley and Sparks (2012), Khuong and Luan (2015) and Oh (1999) have identified that there is a direct and strong positive impact by tourist perceived value on tourists' satisfaction. Thus, the following hypothesis was formed.

$\mathrm{H}_{1}$ : Tourists' perceived value has a positive impact on satisfaction in adventure tourism

\section{Dimensions of Perceived Value and Satisfaction}

In conceptualising the value dimensions, the dimensions presented in the PERVAL value scale were used.

Functional value was defined as the "perceived utility acquired from an alternative's capacity for functional, utilitarian or physical performance" (Sheth et al., 1991, p.160). It was seen as the primary driver of consumer choice (Helkkula, 2009; Sweeney \& Soutar, 2001). The functional value perspective is based on the assumption that customers are objective and rational (Rust, Zeithaml \& Lemon, 2000). Therefore, before a customer makes a purchase, they consider the traditional functional value as trade-offs involving quality, monetary and behaviour price (Rintamaki, Kanto, Kuusela, \& Spence, 2006). Other than quality and reliability, in tourism, the number of attractions seen, on-time performance, comfortableness, and safety all together influence functional value perceptions (Williams \& Soutar, 2009). Further, Williams and Soutar (2009) identified the positive effect of functional value on tourists' satisfaction and thus the following hypothesis was derived.

$\mathrm{H}_{2 \mathrm{a}}$ : Functional value has a positive impact on satisfaction in adventure tourism

Value for money/monetary value is stated as what the customer receives for what they give in and is considered as the monetary cost of the product/experience (Bajs, 2015). Cost of money influences buying decision in distinct ways. Basically, as the amount of money the customer has to pay off in order to exchange/ purchase/ use the product or service and on the other hand it is a quality indicator that implies high price reflects high quality. These two aspects of monetary cost have distinctive influences as there is a negative impact of amount of money spent on perceived 
value and, at the same time, it has a positive impact in the sense of being a quality indicator (Oh, 2003). In contrast, findings of Cronin et al. (2000) indicate that the negative impact of monetary cost is higher than its positive impact towards the perception of quality. Since monetary value has a direct and positive effect on satisfaction (Wang, Lo, Chi, \& Yang, 2004), and that impact is confirmed in the adventure tourism context (Williams \& Soutar, 2009; Williams et al., 2017), the researcher developed a hypothesis to test this impact in the Sri Lankan context as;

$\mathrm{H}_{2 b}$ : Value for money has a positive impact on satisfaction in adventure tourism

Emotional value has identified as a social-psychological dimension which depends on product/service to motivate feelings or the affective states (Sheth et al., 1991). Most of the time, emotional responses are more likely in adventure tourism and its contribution is remarkable. In adventure tourism, emotions play a prominent role and result in emotional 'highs' in exhilaration and excitement such as hesitation, fear and apprehension. Previous studies have found a direct and strong influence of emotions on satisfaction (J. S. Lee, Lee, \& Choi, 2011; Liljander \& Strandvik, 1997; Fluker, 2005) and according to Williams et al. (2017), emotional value is the most influential value dimension on satisfaction among Japanese adventure tourists. Correspondingly, the current researchers expected a positive impact of emotional value on tourists' satisfaction.

$\mathrm{H}_{2 c}$ : Emotional value has a positive impact on satisfaction in adventure tourism.

Social value has been defined as the "perceived utility acquired from an alternative's association with one or more specific social groups" (Sheth et al., 1991, p.161). Social value relates to the social approval and the improvement of the self-image of different individuals (Bearden \& Netemeyer, 1999). Social value links service consumers to a particular social group and includes some aspects such as social self-concept, social image, social identification, expression of personality and quest of social class membership (Holbrook, 1994; Sheth et al., 1991; Sweeney \& Soutar, 2001). Interactions between people during the tour or at the destination, relationship between travellers and the tour guide, individual recognition and the prestige value obtained via participating in the tour/travel experience create social value in a tourism context (Williams \& Soutar, 2009). It is identified that social value is positively related to commitment (Hennig-Thurau, Gwinner, \& Gremler, 2002; Wang et al., 2004) and it has been identified as the key driver for people's interaction in the tourism experience (Chen et al., 2016). Further, in an adventure 
tourism context, social value is supposed to improve satisfaction (Williams \& Soutar, 2009), and the hypothesis was developed as;

$\mathrm{H}_{2 \mathrm{~d}}$ : Social value has a positive impact on satisfaction in adventure tourism

Novelty value/epistemic value was not included in the PERVAL framework initially. Later it was incorporated as a major element related to adventure tourism since it associates with the novelty of the destination and adventure experience (Williams \& Soutar, 2009; Williams et al., 2017). Novelty is one of the major contributors to uncertainty in adventure activities and is about the activity involving an element of doing or experiencing something new (Beard et al., 2011; Williams \& Soutar, 2009). Usually, epistemic value is formed when the product/service experience stimulates curiosity and provides a novel experience (Sheth et al., 1991). According to Beard et al. (2011), if an experience is straightforward, predictable and repeated, it is not considered as an adventure. Consequently, novelty value is one of the major aspects of several adventure tourism products in the sense of the preference among tourists for exploratory, variety seeking and novelty seeking behaviour. Williams and Soutar (2009) have identified a positive impact of novelty value on adventure tourists' satisfaction and thus the following hypothesis was developed:

$\mathrm{H}_{2 \mathrm{e}}$ : Novelty value has a positive impact on satisfaction in adventure tourism

The conceptualised relationships are depicted in Figure 1.

Figure 1: Conceptual Framework

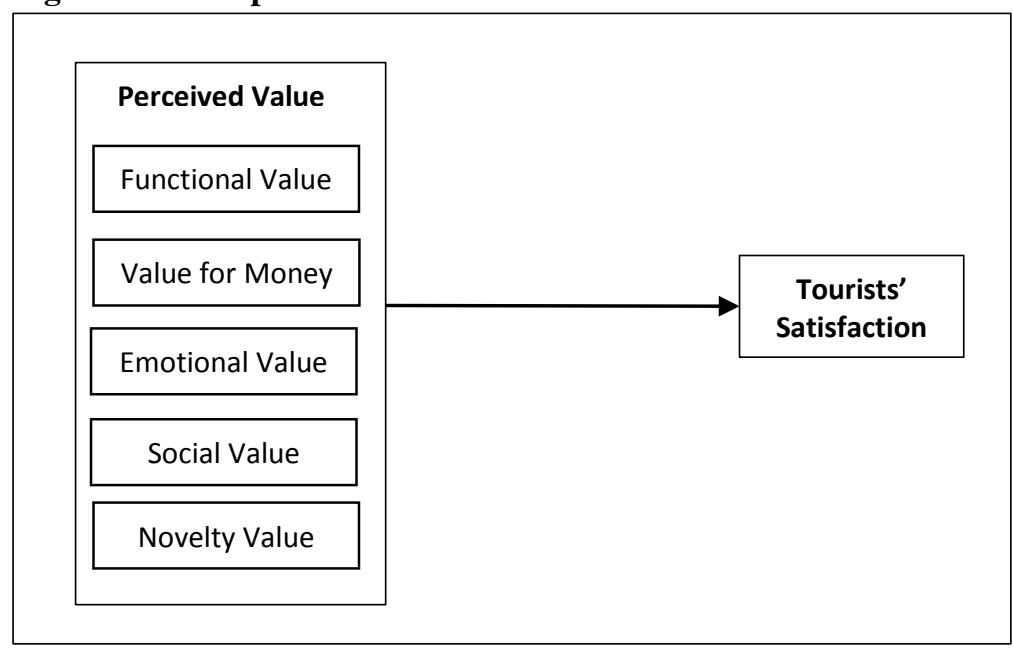

Source: Developed by the author based on Williams and Soutar (2009) 


\section{Measurement Items}

The items measuring the chosen research constructs were adopted from prior related research in the field of perceived value and tourists' satisfaction literature. The impact of each value dimension on the dependent variable was studied through the PERVAL scale which was already developed and empirically tested. Perceived value was measured using a scale derived from Williams and Soutar (2009), which has been developed by Sweeny and Soutar, (2001) (Table 1).

Table 1: Operationalisation of Variables

\begin{tabular}{|c|c|c|}
\hline Construct & Scale item & $\begin{array}{l}\text { Sources of construct } \\
\text { operationalisation }\end{array}$ \\
\hline Functional value & $\begin{array}{l}\text { Consistent quality } \\
\text { Done well } \\
\text { Acceptable standard of quality } \\
\text { Well organized }\end{array}$ & $\begin{array}{l}\text { Williams and Soutar } \\
\text { (2009) }\end{array}$ \\
\hline Value for Money & $\begin{array}{l}\text { Good return for money } \\
\text { Value for money } \\
\text { Good one for the price paid } \\
\text { Reasonably priced }\end{array}$ & $\begin{array}{l}\text { Williams and Soutar } \\
\text { (2009) }\end{array}$ \\
\hline Emotional Value & $\begin{array}{l}\text { Feeling of well being } \\
\text { Exciting } \\
\text { Made me elated/joyful } \\
\text { Feel happy }\end{array}$ & $\begin{array}{l}\text { Williams and Soutar } \\
(2009)\end{array}$ \\
\hline Social Value & $\begin{array}{l}\text { Social approval from others } \\
\text { Feel acceptable to others } \\
\text { Improve the way a person is perceived } \\
\text { Good impression on other people }\end{array}$ & $\begin{array}{l}\text { Williams and Soutar } \\
\text { (2009) }\end{array}$ \\
\hline Novelty Value & $\begin{array}{l}\text { Feel adventurous } \\
\text { Satisfy curiosity } \\
\text { An authentic experience } \\
\text { Did a lot of things during the activity }\end{array}$ & $\begin{array}{l}\text { Williams and Soutar } \\
(2009)\end{array}$ \\
\hline Satisfaction & $\begin{array}{l}\text { Exactly what needed } \\
\text { Satisfied with decision } \\
\text { Wise choice } \\
\text { Good experience }\end{array}$ & $\begin{array}{l}\text { Williams and Soutar } \\
\text { (2009) }\end{array}$ \\
\hline
\end{tabular}

According to Sweeny and Soutar (2001), functional value, value for money, emotional value and social value have been operationalised by using a four-item scale. Novelty value was also derived from the study of Williams and Soutar (2009), as another dimension of perceived value which was initially developed by Weber (2001) and measured using a four-item scale. The dependent variable 
'satisfaction' was measured using a four-item scale based on Williams and Soutar (2009) which was initially suggested by Oliver (1997). Even though those dimensions have been operationalised using 7 point Likert scale where 1 represent Strongly disagree and 7 for Strongly agree, the researcher has used 5 point Likert scale for this study since most of the other social science studies have used 5 point Likert scale.

\section{Methods}

This study deployed a questionnaire survey method to collect primary data where a structured questionnaire was used. This is a quantitative study and according to Saunders, Lewis, and Thornhill, (2009) it can be categorised as an explanatory study. Data was collected from the sample only once. Therefore, this study can be identified as a single cross-sectional analysis (Malhotra \& Birks, 2006). The extent of researcher interference to the study was minimal and the study was conducted in a natural environment with a normal flow of procedures with regard to the research environment and thus this was considered as a non-contrived study.

The research population for this study was considered as all the local adventure tourists in Sri Lanka. An individual who has participated in any kind of land, water or air based adventure activity (see Appendix) in Sri Lanka was identified as the sampling element and it included both male and female who reside in Sri Lanka. The researchers used the convenient sampling technique to select the respondents and both electronic media and hard copy distribution were used to gather data. 350 questionnaires were distributed and 315 were received. A high response rate, 90\% was yielded due to the personal data collection method. After checking the quality of responses, 7 cases were omitted due to missing values and 28 cases were ignored since the respondents had never participated in any kind of adventure activity. Based on 280 complete cases basic analyses were carried out. After removing the outliers (13 cases) in normality test hypotheses tests were carried out by using 267 responses. SPSS 16.0 statistical package was used for the analysis.

\section{Demographic Profile of Sample}

The respondent profile is summarised in Table 2. Out of the 280 respondents, 163 were male and 117 were females. Most of them were in the $18-25$ age category $(\mathrm{n}=139)$ and $170(60.7 \%)$ were unmarried. Majority of the respondents were having a degree which accounted to $43.2 \%$ and $33.9 \%$ respondents belonged 
to the Rs.30,000-60,000 income level while $28.2 \%$ belonged to the below 30,000 income level. However, for this question, some respondents have marked their own income level and full-time students have marked their parents' income level.

Table 2: Demographic Profile of Sample

\begin{tabular}{|c|c|c|c|}
\hline \multicolumn{2}{|c|}{ Characteristics } & \multirow{2}{*}{$\begin{array}{r}\text { Frequency } \\
163\end{array}$} & \multirow{2}{*}{$\begin{array}{r}\% \\
58.2\end{array}$} \\
\hline Gender & Male & & \\
\hline & Female & 117 & 41.8 \\
\hline \multirow[t]{6}{*}{ Age } & Below 18 & 7 & 2.5 \\
\hline & $18-25$ & 139 & 49.6 \\
\hline & $26-30$ & 67 & 23.9 \\
\hline & $31-40$ & 43 & 15.4 \\
\hline & $41-50$ & 15 & 5.4 \\
\hline & Above 50 & 9 & 3.2 \\
\hline Marital & Married & 107 & 38.2 \\
\hline \multirow[t]{2}{*}{ Status } & Unmarried & 170 & 60.7 \\
\hline & Other & 3 & 1.1 \\
\hline Education & $\mathrm{Up}$ to $\mathrm{O} / \mathrm{L}$ & 6 & 2.1 \\
\hline \multirow[t]{4}{*}{ level } & $\mathrm{Up}$ to $\mathrm{A} / \mathrm{L}$ & 69 & 24.6 \\
\hline & Degree & 121 & 43.2 \\
\hline & Above Degree & 25 & 8.9 \\
\hline & $\begin{array}{l}\text { Other professional } \\
\text { qualification }\end{array}$ & 59 & 21.1 \\
\hline Income & Below 30,000 & 79 & 28.2 \\
\hline \multirow[t]{3}{*}{ level } & $30,000-60,000$ & 95 & 33.9 \\
\hline & $60,000-100,000$ & 73 & 26.1 \\
\hline & Above 100,000 & 33 & 11.8 \\
\hline
\end{tabular}

\section{Analysis}

\section{Reliability and Validity}

Internal consistency reliability is where each item of a scale measures some aspect of the construct and the items should be consistent in what they are indicating regarding the construct. As Table 3 depicts, Cronbach's Alpha values of all the dimensions and the dependent variable were greater than 0.7. Thus, it can be emphasised that the reliability of these scales are high.

Since all the indicators were taken from the literature, content validity has been already satisfied which indicates that the scale items have adequately covered the entire domain of the construct measured. Convergent validity is the extent to which the scale items correlate positively with the other measurements within the same construct (Malhotra \& Dash, 2011). As shown in Table 4, Kaiser-Meyer-Olkin 
Measure (KMO) values of the five dimensions and the dependent variable were greater than 0.5, significance of Bartlett's test of Sphericity were less than 0.05, Average Variance Extracted (AVE) values were greater than the recommended minimum of 0.5 and Composite Reliability (CR) values were greater than 0.7. Therefore, convergent validity of all five dimensions and the dependent variable was satisfied.

Table 3: Results of Reliability Test

\begin{tabular}{lc}
\hline Variables & Cronbach's Alpha \\
\hline Satisfaction & 0.912 \\
Perceived Value & 0.946 \\
Functional Value & 0.892 \\
Value for Money & 0.907 \\
Emotional Value & 0.883 \\
Social Value & 0.924 \\
Novelty Value & 0.923 \\
\hline
\end{tabular}

Table 4: Summary of Convergent Validity Results

\begin{tabular}{|c|c|c|c|c|c|}
\hline \multirow[t]{2}{*}{ Variable } & \multirow[t]{2}{*}{ KMO } & \multicolumn{2}{|c|}{$\begin{array}{l}\text { Bartlett's test of } \\
\text { Sphericity }\end{array}$} & \multirow[t]{2}{*}{ AVE } & \multirow[t]{2}{*}{$\begin{array}{l}\text { Composite } \\
\text { reliability }\end{array}$} \\
\hline & & $\mathrm{X}^{2}$ & Sig & & \\
\hline Functional Value & 0.826 & 646.125 & 0.000 & 0.756 & 0.842 \\
\hline Value for Money & 0.837 & 750.421 & 0.000 & 0.785 & 0.866 \\
\hline Emotional Value & 0.798 & 641.482 & 0.000 & 0.744 & 0.833 \\
\hline Social Value & 0.841 & 876.174 & 0.000 & 0.817 & 0.890 \\
\hline Novelty Value & 0.759 & 636.568 & 0.000 & 0.867 & 0.901 \\
\hline Satisfaction & 0.842 & 757.692 & 0.000 & 0.791 & 0.870 \\
\hline
\end{tabular}

Discriminant validity is the extent to which the scale items do not correlate with other constructs from which they are supposed to be different (Malhotra \& Birks, 2006). All squared Pearson Correlation values among constructs were lower than the AVE on the individual constructs and respective other constructs, that satisfied the discriminant validity criterion (Table 5). To test the Uni-dimensional validity, a factor analysis was carried out and when it comes to the final pattern matrix, one indicator of novelty value was eliminated. The rest of 19 indicators were used for further analysis. 
Table 5: Discriminant Validity Results

\begin{tabular}{llccccc}
\hline & \multicolumn{1}{c}{$\begin{array}{c}\text { Functional } \\
\text { Value }\end{array}$} & $\begin{array}{l}\text { Value for } \\
\text { Money }\end{array}$ & $\begin{array}{l}\text { Emotional } \\
\text { Value }\end{array}$ & $\begin{array}{l}\text { Social } \\
\text { Value }\end{array}$ & $\begin{array}{l}\text { Novelty } \\
\text { Value }\end{array}$ \\
\hline Functional Value & $\begin{array}{l}\text { Pearson } \\
\text { Correlation }\end{array}$ & $\mathbf{0 . 7 5 6}$ & & & & \\
Value for Money & $\begin{array}{l}\text { Pearson } \\
\text { Correlation }\end{array}$ & 0.304 & $\mathbf{0 . 7 8 5}$ & & & \\
Emotional Value & $\begin{array}{l}\text { Pearson } \\
\text { Correlation }\end{array}$ & 0.266 & 0.256 & $\mathbf{0 . 7 4 4}$ & & \\
Social Value & $\begin{array}{l}\text { Pearson } \\
\text { Correlation }\end{array}$ & 0.212 & 0.245 & 0.271 & $\mathbf{0 . 8 1 7}$ & \\
Novelty Value & $\begin{array}{l}\text { Pearson } \\
\text { Correlation }\end{array}$ & 0.378 & 0.353 & 0.386 & 0.376 & $\mathbf{0 . 8 6 7}$ \\
\hline
\end{tabular}

According to Sekaran (2003), Skewness and Kurtosis values should lie between +2 and -2 , in order to satisfy the normality requirement. As shown in Table 6, after the removal of outliers (13 outliers), Skewness and Kurtosis of the independent and dependent variables lie between +2 and -2 . Thus, the values were normally distributed.

Table 6: Normality Test Results

\begin{tabular}{|c|c|c|c|c|c|c|c|}
\hline & \multirow[b]{2}{*}{$\mathbf{N}$} & \multirow[b]{2}{*}{ Mean } & \multirow{2}{*}{$\begin{array}{c}\text { Std. } \\
\text { Deviation }\end{array}$} & \multicolumn{2}{|c|}{ Skewness } & \multicolumn{2}{|c|}{ Kurtosis } \\
\hline & & & & Statistic & $\begin{array}{r}\text { Std. } \\
\text { Error }\end{array}$ & Statistic & $\begin{array}{r}\text { Std. } \\
\text { Error } \\
\end{array}$ \\
\hline Functional Value & 267 & 3.9373 & 0.52346 & -0.552 & 0.149 & 0.900 & 0.297 \\
\hline Value for Money & 267 & 3.8071 & 0.70894 & -0.591 & 0.149 & 0.759 & 0.297 \\
\hline Emotional Value & 267 & 4.3006 & 0.61373 & -0.921 & 0.149 & 1.347 & 0.297 \\
\hline Social Value & 267 & 3.7069 & 0.79886 & -0.545 & 0.149 & 0.301 & 0.297 \\
\hline Novelty Value & 267 & 4.1283 & 0.64901 & -0.744 & 0.149 & 1.021 & 0.297 \\
\hline Satisfaction & 267 & 4.1620 & 0.54860 & -0.437 & 0.149 & 0.237 & 0.297 \\
\hline
\end{tabular}

\section{Hypothesis Testing}

Impact of Overall Perceived Value on Satisfaction

Since perceived value can be identified as a second-order formative construct (Mayr \& Zins, 2012), a total mean value for the perceived value can be generated in order to identify the impact and the relationship between the independent and dependent variables. The researcher has applied Simple Regression analysis and since the significance is less than 0.05 (Table 7(b)), it was concluded that the test is statistically significant. As indicated in Table 7(a), R square value of perceived 
value is 0.496 and it expresses that around $50 \%$ of the total variance of tourists' satisfaction was explained by the fitted model with the Beta value of 0.776. Thus, $\mathrm{H}_{1}$ was accepted by emphasising the positive impact of perceived value on tourists' satisfaction. Further, a strong positive relationship between perceived value and satisfaction was identified, since the $\mathrm{R}$ value was 0.704 which represent the Pearson correlation value.

Table 7: Impact of Overall Perceived Value on Satisfaction

7(a) Model Summary

\begin{tabular}{cccc}
\hline $\mathbf{R}$ & $\mathbf{R}^{\mathbf{2}}$ & Adjusted $\mathbf{R}^{\mathbf{2}}$ & $\begin{array}{c}\text { Std. Error of the } \\
\text { Estimate }\end{array}$ \\
\hline $0.704^{\mathrm{a}}$ & 0.496 & 0.494 & 0.39013 \\
\hline
\end{tabular}

Note: aPredictors: (Constant), Perceived Value

7(b) Coefficients ${ }^{a}$

\begin{tabular}{lcrccr}
\hline & & $\begin{array}{r}\text { Unstandardized } \\
\text { Coefficients }\end{array}$ & $\begin{array}{r}\text { Standardized } \\
\text { Coefficients }\end{array}$ & \\
\hline & B & Std. Error & Beta & \multicolumn{1}{c}{ Sig. } \\
\hline (Constant) & 1.077 & 0.192 & & 5.598 & 0.000 \\
Perceived Value & 0.776 & 0.048 & 0.704 & 16.155 & 0.000 \\
\hline
\end{tabular}

Note: ${ }^{a}$ Dependent Variable: Satisfaction

\section{Impact of Perceived Value Dimensions on Satisfaction}

The multiple regression models examined the impact of the respective dimensions of the independent variable on satisfaction. Table 8 indicates the results of the analysis. 'Sig value' strongly suggested the significance of the fitted models. Here, the sig value of ANOVA table was 0.000 which was less than 0.05 and this indicates that the fitted regression model statistically predicts the dependent variable of tourist satisfaction significantly well. As indicated in Table 8(b), all the significance values were less than 0.05 except significance value of social value dimension. This indicated that social value was not statistically significant and it was excluded from the fitted regression model. Thus $\mathrm{H}_{2 \mathrm{a}}, \mathrm{H}_{2 \mathrm{~b}}, \mathrm{H}_{2 \mathrm{c}}$, and $\mathrm{H}_{2 \mathrm{e}}$ were accepted while $\mathrm{H}_{2 \mathrm{~d}}$ was rejected.

R-squared statistic was 0.536 (Table 8(a)) which suggested that value is a key player in predicting satisfaction in the adventure tourism context. Further, it emphasises that $53.6 \%$ of the dependent variable i.e. tourists' satisfaction was explained by the collection of four dimensions of the independent variable, 
functional value, value for money, novelty value and emotional value since the social value dimension was eliminated from the test.

Table 8: Impact of Perceived Value Dimensions on Satisfaction 8(a) Model Summary

\begin{tabular}{cccc}
$\mathbf{R}$ & $\mathbf{R}^{\mathbf{2}}$ & Adjusted $\mathbf{R}^{\mathbf{2}}$ & $\begin{array}{c}\text { Std. Error of the } \\
\text { Estimate }\end{array}$ \\
\hline $0.732^{\mathrm{a}}$ & 0.536 & 0.527 & 0.37716 \\
\hline
\end{tabular}

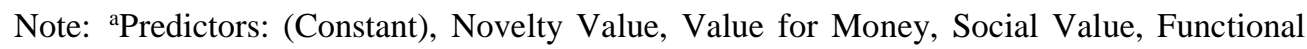
Value, Emotional Value

8(b) Coefficients ${ }^{a}$

\begin{tabular}{lcccccc}
\hline & \multicolumn{2}{c}{$\begin{array}{c}\text { Unstandardized } \\
\text { Coefficients }\end{array}$} & $\begin{array}{c}\text { Standardized } \\
\text { Coefficients }\end{array}$ & \multirow{t}{*}{$\boldsymbol{t}$} & Sig. \\
\cline { 2 - 4 } & B & Std. Error & Beta & & \\
\hline (Constant) & 0.901 & 0.199 & & 4.533 & 0.000 \\
Functional Value & 0.157 & 0.055 & 0.150 & 2.878 & 0.004 \\
Value for Money & 0.110 & 0.039 & 0.142 & 2.791 & 0.006 \\
Emotional Value & 0.222 & 0.053 & 0.248 & 4.183 & 0.000 \\
Social Value & 0.016 & 0.035 & 0.024 & .470 & 0.639 \\
Novelty Value & 0.292 & 0.049 & 0.346 & 5.993 & 0.000 \\
\hline
\end{tabular}

Note: Dependent Variable: Satisfaction

As per the Table 8(b), all the B values were positive. This emphasised that four perceived value dimensions (novelty value, functional value, value for money and emotional value) positively impact on tourists' satisfaction in adventure tourism. Based on the Table 8(b), the following linear equation was formed.

$\mathrm{Y}=a+\beta_{1} \mathrm{X}_{1}+\beta_{2} \mathrm{X}_{2}+\beta_{3} \mathrm{X}_{3}+\beta_{4} \mathrm{X}_{4}+\beta_{5} \mathrm{X}_{5}+\varepsilon$

$\mathrm{Y}=0.901+0.292 \mathrm{X}_{1}+0.222 \mathrm{X}_{2}+0.157 \mathrm{X}_{3}+0.110 \mathrm{X}_{4}+0 . .016 \mathrm{X}_{5}$

$\mathrm{Y}=$ Tourists' satisfaction

$\mathrm{X}_{1}=$ Novelty value

$\mathrm{X}_{2}=$ Emotional value

$\mathrm{X}_{3}=$ Functional value

$\mathrm{X}_{4}=$ Value for money

$\mathrm{X}_{5}=$ Social value 
The regression coefficient of novelty value was 0.292 which highlights that the level of tourists' satisfaction increases by 0.292 when the novelty value increase by one unit while other value dimensions remain constant. Among all the dimensions, novelty value had the strongest influence on tourists' satisfaction. Thus, novelty value was highlighted as the most important predictor of tourists' satisfaction and then emotional value with a beta of 0.227 . Thus, it was suggested that the most prominent value dimension that impacts on tourists' satisfaction was the novelty value in this study context.

The overall summary of hypothesis testing is presented in Table 9 .

Table 9: Summary of Hypotheses Tests

\begin{tabular}{|c|c|}
\hline Hypotheses & Results \\
\hline $\begin{array}{l}\text { H1: Tourists' perceived value has a positive } \\
\text { impact on satisfaction in adventure } \\
\text { tourism }\end{array}$ & $\mathrm{H}_{1}$ accepted \\
\hline $\begin{array}{l}\mathrm{H} 2_{\mathrm{a}} \text { : Functional value has a positive impact } \\
\text { on satisfaction in adventure tourism }\end{array}$ & $\mathrm{H}_{2 \mathrm{a}}$ accepted \\
\hline $\begin{array}{l}\mathrm{H} 2_{\mathrm{b}} \text { : Value for money has a positive impact } \\
\text { on satisfaction in adventure tourism }\end{array}$ & $\mathrm{H}_{2 \mathrm{~b}}$ accepted \\
\hline $\begin{array}{l}\mathrm{H} 2_{\mathrm{c}} \text { : Emotional value has a positive impact } \\
\text { on satisfaction in adventure tourism. }\end{array}$ & $\mathrm{H}_{2 \mathrm{c}}$ accepted \\
\hline $\begin{array}{l}\mathrm{H} 2_{\mathrm{d}}: \text { Social value has a positive impact on } \\
\text { satisfaction in adventure tourism }\end{array}$ & $\mathrm{H}_{2 \mathrm{~d}}$ rejected \\
\hline $\begin{array}{l}\mathrm{H} 2_{\mathrm{e}} \text { : Novelty value has a positive impact on } \\
\text { satisfaction in adventure tourism }\end{array}$ & $\mathrm{H}_{2 \mathrm{e}}$ accepted \\
\hline
\end{tabular}

\section{Discussion}

This research attempted to test the applicability of a number of associations between perceived value and satisfaction suggested in literature, in the adventure tourism context in Sri Lanka. Findings of the study validated a number of previous scholarly work where the customer value has been found as a considerable antecedent on customer satisfaction (e.g., Anderson, Fornell, \& Lehmann, 1994; Bajs, 2015; Cronin et al., 2000; McDougall \& Levesque, 2000).

The main objective of the study was to identify the impact of overall perceived value on satisfaction. The explanatory power of the combined various value constructs was more than $50 \%$ suggesting that perceived value is a major predictor 
of customer satisfaction within the domain of adventure tourism. This finding supports previous scholarly work that identifies perceived value as having a direct and strong effect on tourists' satisfaction (Bajs, 2015; Bradley \& Sparks, 2012; Khuong \& Luan, 2015).

By addressing the second objective of the study, which was to identify the impact of value dimensions on satisfaction, results of the analysis concluded that the novelty value plays a major influence on tourists' satisfaction followed by emotional value. It seems that adventure tour operators who offer especially novelty value and emotional value, are generally expected to have satisfied adventure tour customers. The influence of a multidimensional framework of value was notable and confirmed the prior findings (Roig et al., 2006; Sanchez-Fernandez \& IniestaBonilla, 2007; Sweeney \& Soutar, 2001) as the inclusion of socio-psychological variables (novelty value and emotional value) added superior explanation beyond the traditional value for the money paradigm. Social value dimension was eliminated from the model, since it was not statistically significant, which is a contrast with the findings of Williams \& Soutar (2009) and Chen et al. (2016).

Satisfaction of adventure tourists and all five perceived value dimensions are positively correlated (Williams \& Soutar, 2009) with a Pearson correlation value of 0.704 which indicates a strong positive relationship. This finding was supported by the existing literature of the strong positive relationship between perceived value and tourists' satisfaction (Bradley \& Sparks, 2012; Khuong \& Luan, 2015; Oh, 1999).

Sri Lankan adventure travellers' need to gain novelty highs like thrill, fear, curiosity and authentic experience, where emotional value has been noted as the salient value dimension for Japanese tourists and for Western tourists it was attached as value for money (Williams et al., 2017). According to Chen et al. (2016), social value represented the key driver in peoples' interaction in Arctic tourists' experience. This may be caused because of the cultural and behavioural differences across different nations (Lather et al., 2012). However, emotional value plays the second prominent role in Sri Lankan adventure tourism context and there is little difference between these two variables when concerning the impact on satisfaction (B Coefficients of 0.292 and 0.222). Adventure tour operators need to explore ways to be innovative from time to time to offer an authentic experience and to manage tourists' positive emotions such as enjoyment, happiness, excitement and thrill. Probably, this finding is not surprising in the adventure tourism context 
since hedonism and pursuit of emotional highs like excitement play the main motivation role (Arnould \& Price 1993; Christiansen 1990; Yu, 2012).

Fluker (2005) has suggested that the feeling of satisfaction occur when customers evaluate their perceptions of a particular service performance against their expectations. If perceived performance exceeds expectations, then the tourist is satisfied (Fluker, 2005) without considering the kind of adventure activity he/she has participated in. Thus, the findings of the study confirmed that any kind of land, water or air based outdoor adventure activity which is having a considerable level of risk generates considerably similar kind of satisfaction to the participants. As another major conclusion, findings supported the argument of Buckley (2010) as the behaviour of adventure tourists differ from that of the other kinds of tourists, unlike other major sectors of the commercial tourism industry.

\section{Implications, Limitations and Future Research}

Due to the uniqueness of adventure tourism compared to other kinds of tourism activities, this study is significant within the field of tourism. Further, this research contributes to existing marketing literature. When considering the Sri Lankan context, there were no empirical studies undertaken on this area. Since the uniqueness of different nations (Lather et al., 2012; Williams et al., 2017) application of developed theories may result differently. Hence, this study has provided an understanding of the Sri Lankan domestic tourists' perceived value and satisfaction. Thus, it covered the scarcity of knowledge in this area.

The analysis of consumer behaviour is important to market adventure activity or a destination since it illustrates how and why buyers make decisions to spend their available resources such as money, time and effort on finding, acquisition/purchasing and consumption such kind of experience. A better understanding of consumer behaviour could be effective in formulating marketing strategies and communication. To strengthen the favourable behavioural intentions of consumers, adventure tour operators must acknowledge the expectations of tourists, since they usually compare their expectations against the value in the sense of benefits that they have received after discarding all the sacrifices they have made. That implies adventure tour operators should ensure that their customers are satisfied.

Researchers suggest that the authorities who are focusing to improve tourism, especially within the country and adventure tourism business entities to be more concerned on the novelty experience that they are offering and pay their keen 
attention to thrill, fear and authentic experiences on their promotions. Since the novelty value plays the dominant role in the perceived value and satisfaction association, it is suggested that adventure tour operators need to be innovative and keep exploring the latest improvements in equipment that allow them to design and offer afresh, dynamic and challenging experience. When considering the adventure tourism industry, the only focus is not going to the tour operators who sell and run pre-packaged retail tour products. The number of firms attached to it as adventure equipment, clothing, and property development firms. Hence, the insights generated from this research are valuable to all those parties for the sustainable development of their businesses.

This study was done in a context where there is apparently little recorded information on domestic tourism especially on the participation of adventurous activities. Accordingly, the background statistics used in this study are not totally reliable to make judgments. Convenience sampling method was used to obtain data which is a non-probability sampling method. Due to the time limitation and inconvenience of accessing, North and North East were not substantially covered in the selected sample. Hence, the estimates obtained are not statistically projectable to the population.

Recommendations that can be made for future studies in this field is numerous as it would be more beneficial to conduct more research work over a wider time period by using both quantitative and qualitative methods. The impact of demographic factors on behavioural construct (satisfaction) can be examined. This research only focused on the perceived value of tourists' satisfaction and further reflective constructs can be increased by adding more constructs like revisit or recommendation intention. As the findings of the current study, novelty experience is vital in adventure experience, the impact of it on revisit intention could generate significant findings, since the risk, thrill, and fear may generate different experiences in second participation than in the first-time experience.

Further research is also needed to explore more dimensions in perceived value. The present study was focused on the application of existing developed PERVAL value scale, but there may be other specific value dimensions relevant to adventure consumption. Moreover, tourists can be divided into various categories (e.g. explorers, drifters, wanderlust, sunlust etc.) based on their individual characteristics. Future research can be undertaken in order to identify diverse preferences of different type of tourists in the Sri Lankan domestic tourism context. 


\section{Conclusion}

In conclusion, it is evident that adventure tourism in the global context and in the Sri Lankan context has been growing rapidly. This study added to the existing knowledge on the value construct and its association with satisfaction in the adventure tourism domain with special reference to Sri Lankan domestic adventure tourists. An existing customer value scale (PERVAL) was applied which included different aspects of value in the tourism context and it was and confirmed that value is a more complex phenomena within the tourism context than previously understood. Indeed, it requires a multidimensional value conceptualisation including utilitarian (value for money and functional value) and socio-psychological (novelty value and emotional value) dimensions.

\section{Declaration of Conflicting Interests}

The authors declared no potential conflicts of interest with respect to the research, authorship, and publication of this article.

\section{References}

Agaraj, X., \& Murati, M. (2009). Tourism an important sector of economy development. Annals - Economy Series, Constantin Brancusi University, Faculty of Economics, 1, 83-90.

Anderson, E., Fornell, C., \& Lehmann, D. (1994). Customer satisfaction, market share and profitability: Findings from Sweden. Journal of Marketing, 58(3), 5356. doi:10.2307/1252310

Arnould, E. J., \& Price L. L. (1993). River magic: Extraordinary experience and the extended service encounter. Journal of Consumer Research, 20(1), 24-45. doi:10.1086/209331

Bajs, I. P. (2015). Tourist perceived value, relationship to satisfaction, and behavioral intentions: The example of the Croatian tourist destination Dubrovnik. Journal of Travel Research, 54(1), 122-134. doi: $10.1177 / 0047287513513158$

Bandara, H. M. (2003). Tourism planning in Sri Lanka. Colombo: Stamford Lake (Pvt) Ltd.

Beard, C., Swarbrooke, J., Leckie, S., \& Pomfret, G. (2011). Adventure tourism: The new frontier. Routledge: London

Bearden, W., \& Netemeyer, R. (1999), Handbook of marketing scales: Multi-item measures for marketing and consumer behavior research ( $2^{\text {nd }}$ ed.). London: Sage. 
Bradley G.L., \& Sparks, B. (2012). Antecedents and consequences of consumer value: A longitudinal study of timeshare owners. Journal of Travel Research, 51(2), 191-204. doi:10.1177/0047287510396099

Bruhn, M., \& Egan, J. (2003). Relationship marketing - Management of customer relationships with relationship marketing - Exploring relational strategies in marketing. New Jersey: Multi Pack Pearson Education.

Buckley, R. C. (2007). Adventure tourism products: Price, duration, size, skill, remoteness. Tourism Management, 28, 1428-1433. doi:10.1016/ j.tourman.2006.12.003

Buckley, R. C. (2010). Adventure tourism management. Butterworth-Heinemann: Burlington, MA

Chen, J. S., Prebensen, N. K., \& Muzaffer, U. (2016). Tourist's experience values and people interaction. In J. S. Chen (Ed.), Advances in hospitality and leisure (Vol. 12, pp. 169-179). Emerald Group Publishing Limited. doi:10.1108/ S1745-354220160000012008

Chen, Z., \& Dubinsky, A.J. (2003). A conceptual model of perceived customer value in e-commerce: A preliminary investigation. Psychology and Marketing, 20(4), 323-347. doi:10.1002/mar.10076

Christiansen, D.R. (1990). Adventure tourism. In J. C. Miles \& S. Priest, S (Eds.), Adventure education. State College, PA: Venture Publishing.

Correia, A., Kozak, M., \& Ferradeira, J. (2013). From tourist motivations to tourist satisfaction. International Journal of Culture, Tourism and Hospitality Research, 7(4), 411-424. doi:10.1108/IJCTHR-05-2012-0022

Cronin, J., Brady, M., \& Hult, G. T. (2000). Assessing the effects of quality, value and customer satisfaction on consumer behavioural intentions in service environments. Journal of Retailing, 76(2), 193-218. doi:10.1016/S00224359(00)00028-2

Ewert, A.W., \& Hollenhorst, S. (1989).Testing the adventure model: Empirical support for a model of risk recreation participation. Journal of Leisure Research, 21(2), 124-139. doi:10.1080/00222216.1989.11969794

Fluker, M. (2005). Perceived risk in adventure tourism. (Doctoral thesis). Retrieved from http://vuir.vu.edu.au/1480/

Gallarza, M.G., Saura, I.G., \& Holbrook, M.B. (2011). The value of value: Further excursions on the meaning and role of customer value. Journal of Consumer Behaviour, 10(4), 179-191. doi:10.1002/cb.328

Gill, D., Byslma, B., \& Ouschan, R. (2007). Customer perceived value in a cellar door visit: The impact on behavioural intentions. International Journal of Wine Business Research, 19 (4), 257-75. doi:10.1108/17511060710837418 
Helkkula, A., \& Pihlström, M. (2009). Customer Perceived Value (PERVAL) to Value-in-Context Experience (VALCONEX). Retrieved from http://www.naplesforumonservice.it/uploads/files/HELKKULA_FROM\%20CU STOMER\%20PERCEIVED\%20VALUE\%20-PERVAL-TO\%20VALUE-INCONTEXT\%20EXPERIENCE\%20-VALCONEX-.pdf.

Hennig-Thurau, T., Gwinner, K.P., \& Gremler, D.D. (2002). Understanding relationship marketing outcomes: An integration of relational benefits and relationship quality. Journal of Service Research, 4(3), 230-247. doi:10.1177/1094670502004003006

Heung, V.C.S., Qu, H., \& Chu, R. (2001). The relationship between vacation factors and socio-demographic and travelling characteristics: The case of Japanese leisure travelers. International Journal of Tourism Management, 22(3), 259269. doi:10.1016/S0261-5177(00)00057-1

Holbrook, M. (1994). The nature of customer value, an axiology of services in the consumption experience in service quality. In R. T. Rust \& L. O. Richard (Eds.), New directions in theory and practice (pp.. 21-71). Thousand Oaks, CA. doi:10.4135/9781452229102.n2

Keeling, A. (2003).Getting into action: The UK adventure tourism market. Insights, 14, 383-394.

Khuong, M. N., \& Luan, P. D. (2015). Factors affecting tourists' satisfaction towards Nam Cat Tien National Park, Vietnam - Amediation analysis of perceived value. International Journal of Innovation, Management and Technology, 6(4), 238-243. doi:10.7763/IJIMT.2015.V6.609

Kotler P., \& Keller K. (2006). Marketing management (12 ${ }^{\text {th }}$ ed.). New Jersey: Pearson Education Inc.

Kozak, M., \& Rimmington, M. (2000).Tourist satisfaction with Mallorca, Spain, as an offseason holiday destination. Journal of Travel Research, 38(1), 260-269. doi: $10.1177 / 004728750003800308$

Lather, A. S., Singh, R., \& Singh, A. (2012). Comparing the levels of expectation and satisfaction of Indian and foreign adventure tourists visiting India. Applied Studies in Agribusiness and Commerce, 6(3), 5-13. .

Lee, C. F., (2015). Tourist satisfaction with factory tour experience. International Journal of Culture, Tourism and Hospitality Research, 9(3), 261-277. doi:10.1108/IJCTHR-02-2015-0005

Lee, J. S., Lee, C., \& Choi.Y. (2011). Examining the role of emotional and functional values in festival evaluation. Journal of Travel Research, 50(6), 685696. doi:10.1177/0047287510385465 
Liljander, V., \& Strandvik, T. (1997). Emotions in service satisfaction. International Journal of Service Industry Management, 8(2), 148-169. doi:10.1108/09564239710166272

Lokuhetty, A., Jayawardena, C., \& Mudadeniya, D. (2013).Developing a shared vision for tourism in post-war Sri Lanka. Worldwide Hospitality and Tourism Themes, 5(5), 486-494. doi:10.1108/WHATT-05-2013-0030

Malhotra, N. K., \& Birks, D. F. (2006). Marketing research-An applied approach (Updated $2^{\text {nd }}$ European ed.). Essex, UK: Prentice Hall Pearson Education.

Malhotra, N. K., \& Dash, S. (2011). Marketing research: An applied orientation. ( $5^{\text {th }}$ ed.). Essex, UK: Prentice Hall Pearson Education.

Mayr, T., \& Zins, A. H. (2012). Extensions on the conceptualization of customer perceived value: Insights from the airline industry. International Journal of Culture, Tourism and Hospitality Research, 6(4), 356-376. doi:10.1108/17506181211265086

McDougall, G. H. G., \& Levesque, T, (2000). Customer satisfaction with service: Putting perceived value into the equation. Journal of Services Marketing, 14(5), 392-410. doi:10.1108/08876040010340937

Millington, K., Locke, T., \& Locke, A. (2001). Occasional studies: Adventure travel. Travel and Tourism Analyst, 4, 65-97.

Murphy, P., Pritchard M. P., \& Smith B. (2000).The destination product and its impact on traveller perceptions. Tourism Management, 21(1), 43-52. doi:10.1016/S0261-5177(99)00080-1

Naidoo, P., Ramseook-Munhurrun, P., Seebaluck, N.V., \& Janvier, S. (2015). Investigating the motivation of baby boomers for adventure tourism. Procedia Social and Behavioral Sciences, 175, 244-251. doi:10.1016/ j.sbspro.2015.01.1197

Nature and wildlife, leisure. (2016, October). Time Out Sri Lanka

Oh, H. (1999). Service quality, customer satisfaction and customer value: A holistic perspective. International Journal of Hospitality Management, 18(1), 67-82. doi:10.1016/S0278-4319(98)00047-4

Oh, H. (2003). Price fairness and its asymmetric effects on overall price, quality, and value judgments: The case of an upscale hotel. Tourism Management, 24, 241-249. doi:10.1016/S0261-5177(02)00109-7

Oliver, R. L. (1997).Satisfaction: A behavioural perspective on the consumer. New York: McGraw-Hill.

Oliver, R. L. (2014). Satisfaction: A behavioural perspective on the consumer $\left(2^{\text {nd }}\right.$ ed.). New York: Routledge. 
Patterson, I.R., \& Pan, R. (2007). The motivations of baby boomers to participate in adventure tourism and the implications for adventure tourism providers. Annals of Leisure Research, 10(1), 26-53. doi:10.1080/11745398.2007.9686753

Petrick, J. F. (2001). Development of a multi-dimensional scale for measuring the perceived value of a service. Paper presented at the 32nd Annual Conference of the Travel and Tourism Research Association, Fort Myers, Florida

Rintamaki, T., Kanto, A., Kuusela, H., \& Spence, M.T. (2006). Decomposing the value of department store shopping into utilitarian, hedonic and social dimensions. International Journal of Retail \& Distribution Management, 34(1). doi:10.1108/09590550610642792

Roig, J., Garcia, J., Tena, M., \& Monzonis, J. (2006). Customer perceived value in banking services. International Journal of Bank Marketing, 24(5), 266-283. doi:10.1108/02652320610681729

Rust,T., Zeithaml, A., \&Lemon,N. (2000). Driving customer equity: How customer lifetime value is shaping corporate strategy. New York: The Free Press.

Sanchez, J., Callarisa, L., Rodriguez, R.M., \& Moliner, M.A. (2006), Perceived value of the purchase of a tourism product. Tourism Management, 27(3), 394409. doi:10.1016/j.tourman.2004.11.007

Sanchez-Fernandez, R., \& Iniesta-Bonillo, M. A. (2007). The concept of perceived value: A systematic review of the research. Marketing Theory, 7(4), 427-451. doi:10.1177/1470593107083165

Saunders, M., Lewis, P., \& Thornhill, A. (2009). Research methods for business students (5th ed.). Harlow, England: Pearson Education.

Sekaran, U. (2003). Research methods for business $\left(4^{\text {th }}\right.$ ed.). Carbondale-USA: Hermitage Publishing.

Schott, C. (2007). Selling adventure tourism: A distribution channels perspective. International Journal of Tourism Research, 9(4), 257-274. doi:10.1002/jtr.610

Sheth, J. N., Newman, B. I., \& Gross, B.L. (1991). Consumption values and market choice. Theory and applications. Fort Knox, TX: South Western Publishing

Snoj, B., Pisnik, K.A., \& Mumel, D. (2004). The relationships among perceived quality, perceived risk and perceived product value. Journal of Product \& Brand Management, 13(3), 156-167. doi:10.1108/10610420410538050

Sri Lanka Tourism Development Authority (2016). Annual statistical report 2015. Colombo: Author.

Sung, H.H. (2004). Classification of adventure travelers: Behaviour, decision making, and target markets. Journal of Travel Research, 42(4), 343-356. doi:10.1177/0047287504263028

Sung, H.H., Morrison, A.M., \& O’Leary, J.T. (1996). Definition of adventure travel: conceptual framework for empirical application from the providers' 
perspective. Asia Pacific Journal of Tourism Research, 1(2), 47-67 doi:10.1080/10941669708721975

Sweeney, J., Soutar, G. N., \& Johnson, L. W. (1999). The role of perceived risk in the quality-value relationship: A study in a retail environment. Journal of Retailing, 75(1), 77-105. doi:10.1016/S0022-4359(99)80005-0

Sweeney, J., \&Soutar, G. N. (2001). Consumer perceived value: The development of 127 multiple item scale. Journal of Retailing, 77(1), 203-220. doi:10.1016/S0022-4359(01)00041-0

Tran, X., \& Ralston, L. (2006). Tourist preference influence of unconscious needs. Annals of Tourism Research, 33(2), 424-441. doi:10.1016/j.annals.2005.10.014

Wang, Y., Lo, H.P., Chi, R., \& Yang, Y. (2004). An integrated framework for customer value and customer-relationship-management performance: A customer-based perspective from china. Managing Service Quality, 14(3), 169182. doi:10.1108/09604520410528590

Weber, K. (2001). Outdoor adventure tourism: A review of research approaches. Annals of Tourism Research, 28(2), 360-377. doi:10.1016/S01607383(00)00051-7

Weiler, B., Hall, C.M. (1992). Special interest tourism. New Jersey: John Wiley and Sons

Williams, P., \& Soutar, G. N. (2009). Value, satisfaction and behavioural intentions in an adventure tourism context. Annals of Tourism Research, 36(3), 413-438. doi:10.1016/j.annals.2009.02.002

Williams, P., Soutar, G., Ashill, N. J., \& Naumann, E. (2017). Value drivers and adventure tourism: A comparative analysis of Japanese and Western consumers. Journal of Service Theory and Practice, 27(1), 102-122. doi:10.1108/JSTP-052015-0116

World Tourism Organization (2014). Global report on adventure tourism. Retrieved from https://www.e-unwto.org/doi/book/10.18111/9789284416622

World Tourism Organization (2017). UNWTO tourism highlights 2017 edition. Retrieved from http://mkt.unwto.org/publication/unwto-tourism-highlights

World Travel \& Tourism Council (2018). Travel \& tourism economic impact 2018 Sri Lanka. Retrieved from https://www.wttc.org/-/media/files/reports/economicimpact-research/countries-2018/srilanka2018.pdf

$\mathrm{Yu}$ X. (2012). Co-producing the nature-based adventure tourism experience: tourist, environment and management contributions (Doctoral dissertation). Retrieved from http://hdl.handle.net/2142/34405

Zeithaml, V. A. (1988). Consumer perceptions of price, quality, and value: A means-end model and synthesis of evidence. The Journal of Marketing, 52, $2-$ 22. doi: $10.2307 / 1251446$ 
Zeithaml, V. A., \& Bitner, M. J. (2003). Services marketing: Integrating customer focus across the firm. NewYork: McGraw-Hill Irvin.

\section{Appendix: Adventure Activities Considered in the Present Study}

\begin{tabular}{ll}
\hline Land Based Activities & Water Based Activities \\
Bird Watching & Deep Sea Fishing \\
Wildlife Safaris & Kayaking and Canoeing \\
Cycling and Mountain Biking & Diving and Snorkelling \\
Backpacking/Trekking and Hiking & Surfing \\
Nature Trail and Country Walks & Whale and Dolphin watching \\
Tented Safari Camping & White Water Rafting \& Adventures \\
Rock Climbing/abseiling & Windsurfing / Kite surfing \\
4WD Jeep Adventures & Sailing \\
Rain Forest Exploration & Sky diving and Para Motor Flights \\
Horse Riding & Stream Slides and Confidence jump \\
Aerial Rope & Waterfall Abseiling \\
& Waterfall Climbing \\
Air Based Activities & \\
Hot Air Ballooning & \\
Sea Plane Rides & \\
\hline
\end{tabular}

Source: Nature and wildlife, leisure. (2016, October). Time Out Sri Lanka 